Please do not remove this page

RMIT

UNIVERSITY

\title{
Forced child removal and the politics of national apologies in Australia
}

Cuthbert, Denise; Quartly, Marian

https://researchrepository.rmit.edu.au/esploro/outputs/9921858629201341/filesAndLinks?institution=61RMIT_INST\&index=null

Cuthbert, D., \& Quartly, M. (2013). Forced child removal and the politics of national apologies in Australia. American Indian Quarterly, 37(2), 178-202. https://doi.org/10.5250/amerindiquar.37.1-2.0178

Document Version: Submitted Version

Published Version: https://doi.org/10.5250/amerindiquar.37.1-2.0178

Repository homepage: https://researchrepository.rmit.edu.au (C) 2013 The University of Nebraska Press. All rights reserved.

Downloaded On 2023/04/26 21:17:46 +1000 
Thank you for downloading this document from the RMIT Research Repository.

The RMIT Research Repository is an open access database showcasing the research outputs of RMIT University researchers.

RMIT Research Repository: http://researchbank.rmit.edu.au/

\section{Citation:}

Cuthbert, D and Quartly, M 2013, 'Forced child removal and the politics of national apologies in Australia', American Indian Quarterly, vol. 37, no. 2, pp. 178-202.

See this record in the RMIT Research Repository at:

https://researchbank.rmit.edu.au/view/rmit:21993

Version: Submitted Version

Copyright Statement: (c) 2013 The University of Nebraska Press. All rights reserved.

Link to Published Version:

http://dx.doi.org/10.5250/amerindiquar.37.1-2.0178 


\title{
Forced Child Removal and the Politics of National Apologies in Australia
}

Denise Cuthbert* and Marian Quartly**

*School of Graduate Research, RMIT University, Melbourne, Australia. denise.cuthbert@rmit.edu.au

**School of Philosophy, History and International Studies, Monash University, Melbourne, Australia marian.quartly@monash.edu

\begin{abstract}
In the years between 1992 and 2008 when a formal apology was finally delivered to the Indigenous Stolen Generations, the issue of Indigenous child removal cast a long shadow over Australian culture and society. In 2009 a further national apology - to former child migrants and institutionalised children - was delivered; and, in February 2012, a report of a Senate Committee of inquiry into past adoption practices recommended a national apology to the victims of past adoption in this country. The space of apology has been transformed from one focused on Indigenous-settler relations to a crowded space focused on the suffering associated with child removal. In this paper, we consider the unfolding politics of reconciliation in Australia, and its progressive de-Indigenisation. We conclude that the progressive universalisation of suffering in Australian apology politics, which comes at the cost of sustained engagement with the issues of race- and gender -based power, is damaging to the project of reconciliation and points to an immaturity in Australian politics which must be overcome if genuine reconciliation is to be achieved.
\end{abstract}

Keywords: child removal, Australian Stolen Generations, forced adoption, birth mothers, national apology, indigenous-settler relations, gender

Full Text

Inquiries into the removal and mistreatment of Indigenous and non-Indigenous children, national regret, and national apologies constitute a congested political landscape in contemporary Australia. Within two years, two formal apologies were delivered by the Prime Minister, Kevin Rudd, to individuals who had suffered forced removal from family and consequent mistreatment as children. The first in February 2008 was the apology to the Indigenous Stolen Generations; the second in November 2009 was an apology to forced imperial child migrants, institutionalized children, and wards of the state, the so-called Lost Innocents and Forgotten Australians. These apologies came as the culmination of over a decade of serial formal inquiries that saw at least five national- or state level investigations into the past treatment of children, the results of concerted activism by the groups concerned. 1 In the case of Indigenous activism around child removal, the roots run deep into the twentieth century. For former child migrants and institutionalized children, organized political activity has a shorter history and, as we have argued elsewhere, was enabled by and accelerated to a large degree by the ground prepared by the national inquiry of the Human Rights and Equal 
Opportunity Commission (hreoc) into the Stolen Generations (2005-7), the tabling of its final report, Bringing Them Home, in 1997, the sustained controversy that accompanied the refusal over eleven years of the Liberal-Coalition prime minister, John Howard, to countenance an apology to Indigenous Australians, and the long-delayed apology to the Stolen Generations of 2008.2

Across this congested landscape, the Stolen Generations have cast a long shadow. Non-Indigenous groups with similar claims have rallied in response, often emulating the strategies of Indigenous activists and "benchmarking" their suffering against that of their Indigenous counterparts. 3 In the period following the publication of Bringing Them Home in 1997 and more intensively since the formal apology to Indigenous Australians in February 2008, Australia has been witness to a number of groups and individuals pressing their claims for justice and apology by co-opting or alluding to the term "Stolen Generations" in their own claims. Thus, as documented in this article, both former child migrants and institutionalized children have referred to themselves as the "other" or the "white" Stolen Generations. Further, some non-Indigenous mothers agitating for justice for themselves and their children with respect to the forced removal of their children under past adoption regimes have rallied under the name of the Mothers of the White Stolen Generations.4

Australia has seen an expansion of the space and subject of regret and apology from one initially focused on reconciliation between settlers and Indigenous Australians to one that now encompasses a range of non-Indigenous individuals who were mistreated as children and to whom a formal apology has now been delivered in a second act of national reconciliation. In this process, some slippage has occurred with respect to the relative political positioning of Indigenous child removal as a specific marker of Indigenous dispossession and both suffering and child removal per se as a criterion of suffering that warrants redress and apology. We argue that, instituted as the chief marker of Australian Indigenous suffering in the course of the 1990s, child removal and mistreatment now form the basis of claims for redress and apology of a range of non-Indigenous groups. With the tabling of the reports into the treatment of child migrants and institutionalized Australians in the Australian Senate in 2001 and 2004, respectively, the single volume Bringing Them Home was transformed from an exceptional account of Indigenous suffering to become the first volume in a "trilogy" of national reckoning with past forced children removal in this country, encompassing the experiences of Indigenous and non-Indigenous Australians.5

This trilogy is now a quartet, with the creation in February 2012 of the report of a Senate Committees inquiry into forced child removal for the purposes of adoption. The report includes a recommendation for a national apology amongst its thirteen recommendations. Thus, the space of national apology and regret in Australia is now expanded to include not just children who endured forced removal but the mothers from whom these children were separated. We have dealt in detail with the claims of these mothers for an apology from the Commonwealth elsewhere, but we revisit them briefly in the final section of this article in light of the recently tabled report for the purposes 
of a pointed comparison between the de-Indigenization of Australian reconciliation politics with what we identify as a progressive despecification in the politics of national regret in Australia. 6

From the mid-1990s to the present, the politics of reconciliation and apology in Australia, once exclusively focused on Indigenous people, have been progressively de-Indigenized and, as we discuss in the final section of the article, despecified in other ways as well. In considering how this has come about, we look first to the political foregrounding of child removal as the Indigenous issue par excellence in the discourses of settler-Indigenous reconciliation from the late 1990s to 2008. We suggest that while highly effective on one level in bringing Indigenous Australia to center stage in Australian politics, this issue simultaneously worked to sideline other Indigenous issues (most particularly land rights) from the agenda. At the same time, the focus on child removal and family separation in the politics of Indigenous reconciliation opened a political space for non-Indigenous groups with like grievances to assume a position alongside the Stolen Generations. Our thesis is that the progressive Indigenization of forced child removal and the concomitant sidelining of other political claims of Australia's Indigenous people in the period between 1992 and 2008 has perversely allowed for the replacement of politics by sentiment around the issue of child removal. At the same time, it has opened a political space for non-Indigenous people with similar claims of forced removal as children, resulting in the de-Indigenization of child removal in Australian politics. The consequences of this for the future of the Indigenous-settler reconciliation project are at best uncertain.

\section{SAYING SORRY: FRAMING FORCED CHILD REMOVAL AS AN INDIGENOUS ISSUE}

This discussion in no way challenges the centrality of the issue of forced child removal for those Indigenous people removed from their families as children. We emphatically acknowledge this as a great injustice to Australia's first peoples, a wrong that has inflicted grievous intergenerational harm. Our concern here is with the political and discursive framing of the issue of Indigenous child removal and its reception by non-Indigenous Australia. Such has been the prominence and impact of the Stolen Generations on the shape and complexion of non-Indigenous and Indigenous relations in Australia over the last decade and a half that it is important to remind ourselves that this was not always so. Notably, in December 1992 in his now famous address at Redfern Park in Sydney to launch the Year of Indigenous Peoples, the Labor prime minister, Paul Keating (1991-96), encapsulated the historical and continued injustice to Indigenous Australians in this stark reckoning:

It begins, I think, with the act of recognition. Recognition that it was we who did the dispossessing. We took the traditional lands and smashed the traditional way of life. We brought the disasters. The alcohol. We committed the murders. We took the children from their mothers. We practised discrimination and exclusion. 
It was our ignorance and our prejudice. And our failure to imagine these things being done to us. With some noble exceptions, we failed to make the most basic human response and enter into their hearts and minds. We failed to ask- how would I feel if this were done to me? (Keating, 1992)

The taking of children from their mothers is listed as the fifth of six acts of colonial dispossession and ongoing injustice. Notably, Keating leads this catalog with the primary, defining act of colonial violence on which the other injustices are consequent: "We took the traditional lands." The actors in this historical and ongoing tragedy are "us," non-Indigenous Australians, and our actions are enabled by ignorance, prejudice, and an inhumane failure of imagination: "We failed to ask - how would I feel if this were done to me?"

Keating's words- "we took the children from their mothers"- came to resonate in the years following 1992 and reverberated powerfully during the course of the HREOC inquiry into child removal (199597) and in the publicity surrounding both the inquiry itself and the handing down of the commission's final report in 1997. However, as uttered by Keating at Redfern in 1992, child removal is but one of several crimes and injustices committed by "us" against Indigenous Australians. At the time of this speech, other Indigenous issues loomed much larger in the polity and the popular imagination than removed children. The landmark Mabo decision, which was handed down by the High Court of Australia in June 1992, threw open the question of Indigenous land rights, occasioning countless "outbreaks of hysteria and hostility" in the second half of 1992 to which Keating refers directly in his Redfern address.7 The year 1992 also saw ongoing public debate in the aftermath of the Royal Commission into Aboriginal Deaths in Custody. 8 The multivolume report of the commission, with rafts of recommendations for the criminal justice system, the media, and other bodies in their dealings with Indigenous people at risk of or held in custody, ensured that this issue remained newsworthy and in the public eye. In 1993 a major Senate report on the progress of national reconciliation considered issues ranging from land rights to Indigenous health but made no reference to child removal as an issue for national reconciliation. 9 Child removal was not yet on the reconciliation agenda.

One of the findings of the Royal Commission into Aboriginal Deaths in Custody- that forty-three of the ninety-nine Indigenous deaths in custody it investigated were of people who had been removed from their families- gave traction to the issue of child removal. However, notwithstanding both this finding and Keating's powerful words on child removal in December 1992, it was not until October 1994 that Robert Tickner, the minister for Indigenous affairs, announced that there would be a national inquiry into child removal.10 During the course of the inquiry from 1995 to 1997, and following the tabling of its final report, forced Indigenous child removal became the most popularly recognized issue for Indigenous Australia and the one on which the reconciliation project would come to hinge. 
By 2008, when the former Labor Prime Minister, Kevin Rudd, made his historic apology to Indigenous Australians, the shift in the position of child removal within the catalog of injustices against Indigenous Australians is marked. In a much belated response to one of the recommendations of the HREOc's final report and signaling the rise to preeminence of the Stolen Generations as symbolic of all the wrongs done "by us" to Indigenous people, the terms of Rudd s apology are both an apology to the Stolen Generations and an apology to all Indigenous Australians through consideration of the Stolen Generations. Throughout this speech, Rudd's language slips between the general and the preeminent particular case, with the Stolen Generations and their suffering functioning as synecdoche for the suffering of all Indigenous Australians:

I move:

That today we honour the Indigenous peoples of this land, the oldest continuing cultures in human history.

We reflect on their past mistreatment.

We reflect in particular on the mistreatment of those who were stolen generations- this blemished chapter in our nation's history.

The time has now come for the nation to turn a new page in Australia's history by righting the wrongs of the past and so moving forward with confidence to the future.

We apologise for the laws and policies of successive parliaments and governments that have inflicted profound grief, suffering and loss on these our fellow Australians.

We apologise especially for the removal of Aboriginal and Torres Strait Islander children from their families, their communities and their country.

For the pain, suffering and hurt of these stolen generations, their descendants and for their families left behind, we say sorry.

To the mothers and the fathers, the brothers and the sisters, for the breaking up of families and communities, we say sorry.

And for the indignity and degradation thus inflicted on a proud people and a proud culture, we say sorry.11

Rather than itemizing individually the injustices against Indigenous Australians as Keating did in 1992, Rudd moves directly from a statement of the general case of "past mistreatment" to the preeminent case, the Stolen Generations, as symbolic of all Indigenous pain and suffering: "We 
reflect in particular on the mistreatment of those who were the stolen generations- this blemished chapter in our nation's history" (emphasis added). With similar effect, Rudd casts the apology in general terms "for the laws and policies of successive parliaments and governments" and then moves directly to the particular: "especially for the removal of ... children from their families" (emphasis added). The "indignity and degradation" referred to by the prime minister in his speech is that which has been inflicted on the "proud people and ... culture" of the first nations through the removal of children and the consequent "breaking up of families and communities."

A number of points may be made about the terms of this apology, in particular, its emphasis on "past mistreatment," which contrasts with Keating's insistence in 1992 that injustices against Indigenous Australians are both historical and ongoing. The point that has significance for the current discussion is that by February 2008, the prominence of the Stolen Generations was such that an apology to them by the Australian prime minister could be cast in terms of, and understood by the nation as, being the equivalent of an apology to all Indigenous Australians, as this excerpt from the editorial of the Age, a major Australian daily newspaper, makes clear: "But to Indigenous Australia the axis of their world will have changed because something will have been returned to them. That something is respect; and with that must come hope that what they have seen, white Australia now sees too. And white Australia says sorry also, for all these wasted years of looking the other way."12

Without diminishing the enormous symbolic importance of this apology or the importance of the issue of forced child removal for many Indigenous people and communities, it is salutary to consider why and with what consequences the issue of child removal gained such political and popular traction over the sixteen years from 1992 to 2008 to emerge as the preeminent and defining issue of Indigenous Australia. As observed by one commentator, the Stolen Generations and the apology to them came to occupy "the moral core of the nation," with the effect of sidelining other claims by Indigenous Australians of systemic injustices that had been the focus of concerted activism for decades.13 These claims include land rights, differential treatment by the criminal justice system and the continuing high rates of incarceration, human rights abuses, poverty, health, chronic disease and mortality rates, and lack of access to education and employment.14 Decades of Indigenous activism and other interventions, such as the Royal Commission on black deaths in custody, largely failed to bring about positive change for Indigenous Australians or (and there is likely a causal connection here) to secure the sustained attention of non-Indigenous Australia.

Why did the suffering of the Stolen Generations become the Indigenous issue to which nonIndigenous Australians were prepared en masse (with some notable and vocal exceptions) in the Sorry Day marches and the production of tens of thousands of Sorry Books to subscribe?15 One possible reason, we suggest, is the centrality of the plight of innocent children to the Stolen Generations issue and through this the appearance of this issue as being above or beyond the 
otherwise messy, intractable, and highly political politics of Indigenous-settler relations in Australia. For many non-Indigenous Australians, vexed and divided on issues such as land rights, alcoholism, and law and order in Indigenous communities, the issue of the Stolen Generations, while hard to confront, appeared more straightforward. This was not a matter of politics. It was about the suffering of innocent children and their removal from their families.

As we argue below, the progressive political and discursive "Indigenization" of forced child removal worked distortions in the political positioning of settler-Indigenous relations in Australia, including the sidelining of other Indigenous issues from the reconciliation agenda. With notable exceptions, including the efforts of Stolen Generation deniers on the extreme right, the prevailing mode of discourse became one of sentimentalization centered on the suffering of children rather than political and other restitution for Indigenous Australians. Political momentum on Indigenous reconciliation has also been slowed by the emergence of non-Indigenous groups making parallel claims to Indigenous people on the basis of their forced removal from family and community as children. The discursive and imaginative space of forced child removal has become progressively crowded with non-Indigenous groups with like claims of profound childhood suffering and injustice.

\section{"HOW WOULD I FEEL IF THIS WERE DONE TO ME?": THE POLITICAL EMERGENCE OF "OTHER" STOLEN GENERATIONS}

In Keating's Redfern speech in 1992 and more emphatically in Rudd s apology to the Stolen Generations in 2008 , the issue of the forced removal of children is framed specifically and characteristically as an Indigenous experience. Australian historian Bain Attwood has formulated a thesis of "narrative accrual" to explain how diverse Indigenous experiences came to be discursively organized in relation to the growing influence of the Stolen Generations narrative.16 In a political corollary to this, the removal of children had crystallized by the time Rudd spoke in 2008 as the defining experience of being Indigenous in Australia. By reason of this, as argued above, the apology to the Stolen Generations in February 2008 was understood by the nation as an apology to all Indigenous people (whether they had been "stolen" or not).

Some sense of the distance assumed by Paul Keating between the suffering endured by Indigenous Australians and the life expectations of non-Indigenous Australians is measured out in his claim of "our" failure to imagine how it would feel if such things were done to us. Keating's words assume that, for the majority of white Australians, things such as the expropriation of lands and the removal of children lie outside our experience and hence require imagination to apprehend. By 2008 the forced removal of children had become not only a defining experience of Indigeneity in Australia but the defining experience, and it has been made to stand for all other injustices and mistreatment endured by our first peoples. 
However, for numbers of non-Indigenous Australians listening to Keating's words in 1992 and Rudd's later apology, the question, How would I feel if this were done to me? was able to be readily answered in relation to forced child removal. Non-Indigenous Australians knew how it felt. It had been done to them. And, as many groups and individuals were keen to point out, many of them had shared their suffering with their Indigenous peers:

I was with Indigenous friends ... on that wonderful and remarkable morning in Australia's history when Prime Minister Rudd read his heartfelt Apology on behalf Our Nation. . . . Like me, many of the Forgotten Australians and Migrant Children shared some of their childhood in the same institutions as the Stolen Generation and those words of acknowledgement and apology are just as strong and important for us too; we also long to hear and take into our hearts those precious words of Apology from our Nations [sic] leader for the Understanding and Healing they offer and hold.17

While many non-Indigenous adults removed from their families "rejoiced" in the apology to the Stolen Generations, 18 they nonetheless asked questions:

It was a great day in Australia's national life when [the apology] was finally delivered. Prime Minister Rudd gave not just an apology to the stolen generation but a promise of much more remedial action to come. The committee needs to ask the federal government the question being asked by white children who were harmed in care: where is their apology?19

[Many Forgotten Australians] really appreciated the stolen generations apology. That was a massive occasion for many of our members. For many of them it brought tears that there had been an acknowledgement for those people, but it also brought tears of the other sort: "Why not us?"20

What is the difference between the Aboriginals and us? It is great that they've had their apology but the only difference is the colour of our skin. When are we going to get our apology?21

In one of the complex ironies of this episode in Australian history, the issue of child removal, which had come progressively to define Indigenous Australia in the eyes of many non-Indigenous Australians between 1992 and 2008, readily also became an issue by which particular groups of nonIndigenous Australians also defined themselves and on which they now made their claims for an apology comparable to that given to the Stolen Generations pursuing the same methods of agitation for a national inquiry.

There are complex racial politics involved in this shift in the politics of reconciliation in Australia. Two elements may be noted here. First, a major plank of the right-wing opposition to the Stolen 
Generations and their claim for an apology took the form of an argument that the removal of Indigenous children was not racially based but rather a function of welfare policies and practices: to wit, Indigenous children were not removed because they were black; rather, they were removed because they were neglected, along with other at-risk children, irrespective of their race. This line of argument was crucial in the political Right's attempt to uncouple Indigenous child removal from charges of attempted genocide and was rehearsed repeatedly by conservative commentators in the eleven-year lag between the HREOC's final report and the apology of 2008.22 This lag coincided with the term of the conservative government of Prime Minister John Howard (1996-2007), which steadfastly refused to apologize to Indigenous Australians, as recommended by the HREOC in its final report.

Second, and not unrelated to this first consideration, the statement of claims by members of nonIndigenous groups of formerly removed children and those of the self-designated Mothers of the White Stolen Generation whose babies were removed from them for the purposes of adoption, discussed further below, can appear as those of resentful whites, prepared to play the "race card" in pursuit of their claims: "So why does one section of the population get an apology but not the other? Why is there racial discrimination? Why does one group matter less than the other? That is the question to be asked loudly. I would hate the answer to be 'politics'."23 Of course, the answer to this (and nearly every other question that arises from this matter) is politics. The political prominence secured by the Stolen Generations and the apology of 2008 provided both a platform and a precedent for the causes of the non-Indigenous people who also endured family separation. What had been framed as an Indigenous issue for national reconciliation and thus gained more broadly based popular support than any other Indigenous issue before (or since) also proved ripe for co-opting by non-Indigenous groups with similar claims. Groups of non-Indigenous removed children began to frame their cause directly in terms of the Indigenous Stolen Generations. Thus, journalist Richard Yallop wrote in 2004:

First there was the Human Rights and Equal Opportunity Commission's 1997 Bringing Them Home report on the separation of Aboriginal children from their families - the so-called "stolen generation" report. Then there was the 2001 Senate Lost Innocents inquiry into the child migrants from Britain and Ireland who were abused in Australian institutions. Finally, in a report revealing real institutionalised sadism and maltreatment as lurid as anything created by the imagination of Charles Dickens, the Senate's community affairs committee has opened the lid on what happened to "ordinary" white Australian children who, for one reason or another, ended up in orphanages or children's homes. It has been described by some as the "white stolen generation" report.24

Thus, the HREOC report began to be reframed not so much as a watershed report into Indigenous experiences and a crucial document in the process of Indigenous-settler reconciliation in Australia 
but as the first in a series of reports that highlight the past mistreatment of children by the state and its agents. The yoking together of these reports- that is, the HREOC report into child removal along with the Australian Senate reports into forced child migration and institutionalized childreninto a trilogy on removed children also occurs at several points in the proceedings and the report of the Senate Standing Committee on Community Affairs, which revisited both the Forgotten Australians and Lost Innocents inquiries in 2009.25 Joanna Penglase from Care Leavers Australia Network writes:

The current Senate Inquiry [2009] is a welcome beginning to understanding just what happened, and why. This Inquiry into Children in Institutional Care, clan regards as the third of the trilogy-after the inquiry into the Stolen Generations and into the experiences of the Child Migrants.

Although the Aboriginal history has its own uniquely catastrophic dimensions, there is one major point of similarity between that history and ours.

Children, regardless of the colour of their skin, are deeply wounded psychologically by the loss of their parents; and they do not thrive, indeed they barely survive, in the sterile environment of an institution (in which so many Aboriginal children also suffered). 26

Andrew Murray, the former Western Australian senator who was instrumental in bringing the plight of former child migrants into the national spotlight, also considered the Senates inquiries into these other groups of removed children to represent the "rounding off [of] a trilogy of reports on the treatment of children in Australia following the earlier report Bringing Them Home by the Human Rights and Equal Opportunity Commission."27 In this way, the Stolen Generations themselves not only came to signal a shift in the collective memory in Indigenous-settler relations but were readily recoded to signal shifts in the historic reckoning on the past treatment of children, black and white. Several statements from this same inquiry register this shift, for example:

On 13 February 2008 the world changed in relation to historical abuse, when the Prime Minister apologised on behalf of the government and the people of Australia to the stolen generation. This was an historic moment. We listened very carefully to the Prime Minister's sentiments. This was recognition, indeed, and long awaited. Our pain, suffering and injustice continues [sic] to this very day. We feel the degree of discrimination. Australia can no longer live in denial of a painful, shameful chapter of child and family abuse in relation to former child migrants and their families. 28

As cited above, on the day of the apology itself the editor of the Age wrote that "the axis of the world changed" for Indigenous Australians. By the middle of 2009 the change effected on that historic day in $\mathbf{2 0 0 8}$ was being actively recast from one that focused on Indigenous peoples and a shift in the axis of their world to "a world changed in relation to historical abuse" of all children. The 
apology to Indigenous Australians is here effectively co-opted by non-Indigenous Australia to represent a signal moment in the reckoning of more generalized "historical abuse." Injustice to Indigenous people had already been symbolically reduced to the suffering of the Stolen Generations of children and their families. At this point it is transformed and effectively de-Indigenized to emerge as the suffering of children.

It might be argued that the child-centric terms of the Stolen Generations discourse and the apology of 2008 have now seen their removal from the sphere of Indigenous politics and their reconstitution within the claims for justice by non-Indigenous Australians for redress of their childhood suffering at the hands of the state. Despite the earlier framing of forcible child removal as the preeminent Indigenous issue, unfolding reconciliation politics in Australia have partially subsumed the Indigeneity of the Stolen Generations into the category of the removed and damaged child whose suffering is both above politics and "not divisible by race":

Like the Indigenous children, many non-Indigenous children were taken from their country and stolen from their families. Like the Indigenous children, they too were sexually assaulted. They too were physically assaulted. Read all the reports and books. The sufferings of children in care are not divisible by race. 29

Non-Indigenous activists trod a fine line in presenting their claims as comparable to those of the Stolen Generations without challenging Indigenous claims for justice and apology, as these Indigenous claims provided a precedent for their own. This often came down to a kind of grim accounting of suffering, as in this passage from an essay by Joanne Penglase of clan:

The older generation of "wardies" [former wards of the state] and "Homies" [former residents of children's homes] are the forgotten, and perhaps even the hidden generations. We number hundreds of thousands across Australia, more than the Aboriginal Stolen Generations, more than the adoptees who have services in every state, more than the child migrants who numbered at most ten thousand people. This is not to deny in any way the significance of those tragic histories or the right of those groups to recognition and to services. 30

Non-Indigenous claimants for a national apology saw the political and moral opportunity provided by the apology to the Stolen Generations in advancing their own claims. Signaling the degree to which the Stolen Generations were now being mobilized as an emblem not only of the injustices done to Indigenous people but of the sufferings of all removed children, political discourses following the apology to Indigenous Stolen Generations highlight the parallels between their plight and that of Indigenous people removed as children. Expressing this alignment and their comparable grounds for an apology, groups and individuals began applying to themselves terms including the "other Stolen Generation," the "white Stolen Generation," and, in the case of mothers separated 
from their children by past adoption practices, Mothers of the White Stolen Generation.31 Typical of this repositioning, James Luthy, a Forgotten Australian, institutionalized in a Salvation Army boy's home in Goulbourn following removal from his family, wrote to the Australian Senate in 2009 on the implementation of the recommendations from the Forgotten Australian and Lost Innocents inquiries and added the epithet "Stolen White Generation" to that of "Forgotten Australian" in introducing himself:

I am one of the Forgotten Australians I was part of the "Stolen White Generation" and I was incarcerated by The Salvation Army in the Gill Memorial Home for Boys in Goulburn NSW. ... $[T]$ he "White Stolen Generation" ... suffered as much as the Indigenous children. ... An apology for the cruelties suffered by innocent children will enable people to move on with their lives.32

In securing their apology in November 2009, non-Indigenous adults removed from their families as children succeeded in expanding the political and emotional space opened up by the Stolen Generations to include their own experiences of forced removal, institutionalization, suffering, and abuse. The second apology delivered by the prime minister to the groups of non-Indigenous removed children, even more than the apology to the Stolen Generations, emphasized their status as children when the abuses occurred and their innocence. $33 \mathrm{In}$ the transformation of the politics of apology in Australia, at least two elements emerge very clearly: by 2009 reconciliation was no longer an exclusively Indigenous issue; and innocence, ideally childhood innocence, appears to be a precondition for receiving a national apology in Australia.

\section{DE-INDIGENIZED CHILD REMOVAL: THE UNIVERSAL CHILD AT THE CENTER OF THE NATION'S REGRET}

In making his second national apology in November 2009, Rudd stressed more strongly than in his words to the Stolen Generations the pain and trauma suffered by institutionalized children, "the physical suffering, ... the cold absence of love, of tenderness, of care." To the litany "we are sorry," Rudd added the refrain "we look back with shame," saying, "We look back with shame that many of these little ones who were entrusted to institutions and foster homes instead, were abused physically, humiliated cruelly, violated sexually." He stressed the fault of the nation: "You were in no way to blame for what happened to you because it was the nation who failed you. The institutions the nation created for your care, failed you." He reiterated both past and continuing pain:

We recognise the pain you have suffered.

Pain is so very, very personal.

Pain is so profoundly disabling.

So, let us together, as a nation, allow this apology to begin to heal this pain.34 
Inasmuch as the federal government has apologized to the Stolen Generations, the Forgotten Australians, and the Lost Innocents, the apologies have been directed primarily at "children." Kevin Rudd noted in the course of his apology of 2009 that he had been privileged "to meet some of these children, most of them now middle-aged." By fixing on the idea that the children were victims of an adult society that failed to care for them and that the children, by extension, were the ones who deserved an apology, the federal government has faced the question of ongoing adult suffering only obliquely. "We come together ... to say to you," Rudd announced, "that we are sorry" for "those who were sent to our shores as children without your consent," "robbed of your families, robbed of your homeland, regarded not as innocent children but regarded instead as a source of child labour ... for the protection of children is the sacred duty of us all." By couching the apology in these terms, Rudd invoked the idea that children are vulnerable innocents, incapable of wrongdoing unless led astray. The corollary of the idea of children as innocents is the view of adults as rational beings, having gained in their adulthood a capacity for dealing with moral issues. When he reminds the Forgotten Australians that "you were in no way to blame for what happened to you," Rudd enters a conceptual space where entitlement to apology appears to depend on this kind of "innocence."

In the terms set out by Melissa Nobles in her consideration of the politics of national apologies, the former institutionalized and immigrant children are included in "national membership" through the apology delivered to them more as innocent children who were wronged by the state decades ago and less as the adults they have become. 35 The privileging of the innocence of childhood and its indivisibility by race at the center of Australian apology politics has by this point almost completely erased the distinctiveness of the claims of Indigenous Australians, centered as they had become on forced child removal and the consequent suffering of children. National regret and reconciliation, having shifted from an exclusive focus on the wrongs done to Indigenous peoples to include wrongs done to several groups of forcibly removed children, is now under further pressure to shift again to include an apology to mothers of children forcibly removed, specifically, mothers of children removed for the purposes of adoption in the period from 1950 to 1975.

\section{NEUTRALIZING GENDER IN PAST ADOPTION PRACTICES}

In February 2012, after an inquiry that ran for more than twelve months and received over four hundred written submissions, the Australian Senates Reference Committee on Social Affairs tabled its final report into the forced removal of children from mothers under past policies and practices in adoption. This report- Commonwealth Contribution to Past Forced Adoption Practices- runs to over three hundred pages of harrowing testimony of forced and coercive child removal in Australian state- and church-run maternity hospitals. Like the major reports into Indigenous and other child removal that precede it, the report recommends an apology to the victims of these practices. The second of thirteen recommendations reads: 
that the Commonwealth Government issue a formal statement of apology that identifies the actions and policies that resulted in forced adoption and acknowledges, on behalf of the nation, the harm suffered by many parents whose children were forcibly removed and by the children who were separated from their parents."36

In contrast to the reports that precede it, while taking up the issue of forced child removal, this inquiry and report focused primarily on the treatment of the mothers from whom children were removed, and, while acknowledging the harm suffered by the removed children, the consequences for these children remain of secondary concern. Thus, the space of apology and regret in Australia, which has shifted and slipped from one focused on Indigenous suffering to one in which the specificities of Indigenous loss and suffering are subsumed into the suffering of universalized abused childhood, goes through a further shift as non-Indigenous adults are included in the space of apology. Significantly, yet again, specificity is lost in this process. Just as the specificities of race and Indigenous experience were occluded in the transition of the focus of national regret to removed and suffering children "indivisible by race" outlined in the first part of this article, in this latest transition - still in process as we write in the interval between the tabling of the report and the decision of the government on the question of an apology - the specificities of gender and gendered norms of sexual and reproductive conduct appear to have given way to a more general framing of the harms inflicted on the nongendered parents of forcibly removed children.37 Notably, and as we discuss in more detail below, the highly gendered impact of past forced adoption practices, in which infants were removed from single unmarried mothers to be placed in "respectable" homes, risks being elided in the terms of the report's recommendation for an apology that does not acknowledge the particular pain of mothers nor the wrongs done to women but "the harm suffered by many parents" under these coercive regimes.

In an earlier provisional attempt to unravel the complex politics of culture, race, and gender at work in Australian apology politics with respect to the claims of birth mothers for redress and apology, we theorized that the space of apology in Australia had through the first decade of this century become so child-centric and so predicated on innocence as a precondition for apology that it was difficult to imagine the terms in which any national apology to these women might be cast.38 By reason of their transgression of sexual and reproductive mores, the mothers separated from their children by past adoption practices did not readily comply with the requirements of childhood (although many of these mothers had not attained their own majority at the time of their confinements) nor of innocence, which appear to have become the preconditions for apology in Australia. Such were our misgivings, we speculated whether any such apology would be forthcoming. Recent events appear to have resolved the latter question: it now seems that it will only be a matter of time before the Commonwealth government issues an apology for its role in past forced adoption practices. However, the wording of the Senate report's recommendation indicates that the way in which this 
forthcoming apology is framed remains an issue with bearings on the current state of Indigenous reconciliation in Australia.

Overwhelmingly, as we have documented elsewhere, political activism on the question of the abuses entailed in former forced adoption practices has been undertaken by mothers who lost children to adoption, and this political arena is occupied by a number of highly active and effective mothers' groups and organizations.39 Likewise, overwhelmingly, the submissions received by the Senate committee - like those received in two earlier state inquiries in New South Wales and Tasmania have been written by women whose children were taken from them.40 Women, in their written submissions and verbal testimonies in the public hearings of inquiries in Tasmania in 1999, in New South Wales in 1999 and 2000, and in the public hearings in every state and territory conducted as part of the Senate inquiry of 2011-12, highlight the highly gendered nature of their experiences - of the shame and ostracism entailed in unmarried pregnancy, of desertion (with rare exceptions) by the fathers of their children, of hardship and abuse in judgmental, moralistic maternity homes, of shoddy and sometimes cruel and abusive treatment by hospital staff during their confinements, and of confinements that brought their own horrors of inadequate pain relief, pillows over faces to obscure any sight of their child, and of children being whisked away to nurseries without mothers seeing or holding them. There is, of course, also evidence provided by children relinquished for adoption, by the fathers of children lost to adoption, and by adoptive parents - but this material represents a very small proportion of submissions received by any of these three inquiries. The Australian material and its strongly gendered story of the impact of adoption resonates with accounts of former adoption practices in other comparable jurisdictions provided for the United States by Ann Fessier, for Canada by Veronica Strong-Boag, and for the UK by Jenny Keating.41 Extending Laura Briggs s axiom regarding the production of adoptable children, the Australian experience demonstrates compellingly that child removal bears an indexical relationship to vulnerability, which is both gendered and classed.42

The document produced by the Australian Senate committee is overwhelmingly a report on the gendered impact of forced adoption practices on the mothers who endured the removal of their children. By way of quantifying this, it is notable that the terms "mother" and "mothers" appear 753 times in the report, while the terms "father" and "fathers" appear 126 times. This proportion reflects the gender ratio in both written submissions and verbal testimonies to the Senate committee. While responding to and fully documenting the gendered impact of past adoption regimes in the conduct of the inquiry and throughout the report, in its recommendation on the terms of the apology, the Senate committee appears to take a step back from this specificity and recommends instead a more inclusive and gender-neutral form of apology for parents and children harmed by past adoption practices. This stepping back from fully confronting the gendered (and classed) structures of power and powerlessness that led to the flourishing of forced and coercive practices in adoption in the decades following the end of World War II, which so palpably worked against the interests of 
unmarried women and their children and so clearly favored the interests of "respectable" middleclass married couples seeking children for family formation, echoes and repeats the progressive deIndigenization of the issue of child removal that has occurred in Australia and raises doubts as to the political efficacy of the apology process as undertaken in Australia.

\section{IMPLICATIONS FOR THE FUTURE OF INDIGENOUS-SETTLER RECONCILIATION}

This article maps complex shifts in the space of apology and regret in Australian national politics. We have argued that child removal became progressively Indigenized (at the expense of other important issues in the Indigenous reconciliation agenda) only finally to become de-Indigenized with the figure of historical injustice shifting from that of the Indigenous victim to that of the Indigenous child victim and finally to that of a universalised child victim in the terms of the 2009 apology to the Forgotten Australians and the Lost Innocents. In the 2012 report on past adoption practices, the entitlement to apology in Australian politics has strained to accommodate the highly gendered claims for recognition and redress mounted by non-Indigenous mothers separated from children through adoption practices. While the report documents this gendered suffering, the recommended apology recoils from confronting the gendered nature of power and powerlessness in Australia and resorts, instead, to recognition of the gender- neutralized and generalized harms endured by parents and children under past adoption regimes.

This is, we suggest, a corollary to the progressive retreat from sustained engagement with the issue of power and powerlessness underpinned by race and Indigeneity in the nation's engagement with the Stolen Generations. This retreat was already under way at the time of the 2008 apology to the Stolen Generations and is manifest in the terms of that apology, which, as discussed above, focus on the past suffering of children and glance only obliquely at the ongoing suffering and injustices of Australia's first peoples. In the terms of Kevin Rudd s apology, injustice to Indigenous Australians is a matter of history, with the apology closing that shameful past chapter in Australian history.

The efforts of the Australian government in the arena of national apology are commendable. Nonetheless, these apologies remain deficient on several grounds. A mature politics of apology would not allow the gaze of the nation to be averted so readily from the specific realities that must be confronted to despecified and universalized figures of victimhood as we have seen in Australia. Injustice underpinned by race and gender must be addressed as such. Violence and harm instituted and maintained through power structures based on race, class, or gender likewise must be acknowledged and not dealt with merely as bad things that happened to some people- and mostly to children- in the past. A more mature politics of apology and reconciliation would not elide race by installing a universalized figure of childhood suffering in the center of the reconciliation stage, just as it would not allow the specifics of gender-based power in the forced removal of children for adoption to be elided in favor of the figure of a suffering, gender-neutralized parent whose 
installation occludes the specific sufferings of women at the heart of these practices. A mature politics of apology must be sufficiently robust to accommodate difference in that different groups endured the tragedy of forced child removal for different reasons, all explicable through an historicized understanding of vulnerability and disadvantage. The suffering of all such victims must be specifically acknowledged without the claims of one group superseding or diminishing the claims of others. That is, it is not enough to say sorry without fully articulating the grounds on which the wrongs were done. It is only through a sustained and historically informed acknowledgment of the power structures that lead to such injustices that we can ensure that they are not repeated.43 The Australian space of apology- now occupied by a universalized suffering child and shortly, it seems, to be joined by a gender-neutral suffering parent, victims indivisible by either race or gender- is still some way from this maturity.

\section{ACKNOWLEDGMENTS}

The authors gratefully acknowledge the Australian Research Council's support for the research reported in this article and the valuable commentary provided on an earlier draft by scholars involved in the roundtable on Indigenous child removal at the Berkshire Women's History Conference (2011), convened by Prof. Margaret Jacobs. Thanks are also extended to Dr. Margaret Taft for her assistance in preparing this article for publication.

\section{Footnote}

NOTES

1. These reports include Human Rights and Equal Opportunity Commission, Bringing Them Home: Report of the National Inquiry into the Separation of Aboriginal and Torres Strait Islander Children from Their Families 1997 (Canberra: Human Rights and Equal Opportunity Commission, Commonwealth of Australia), available at http://www.hreoc.gov.au/pdf/social_justice/bringing_them_home_report.pdf; Parliament of Tasmania, Past Adoption Practices (Hobart, 1999); New South Wales Parliament, Legislative Council, Standing Committee on Social Issues, Releasing the Past: Adoption Practices 1950-1998 (Sydney, 2000); Senate Community Affairs References Committee, Lost Innocents: Righting the RecordReport on Child Migration, 30 August 2001 (Commonwealth of Australia, 2001); Senate Community Affairs References Committee, Forgotten Australians: A Report on Australians Who Experienced Institutional or Out-of-Home Care as Children, 30 August 2004 (Commonwealth of Australia, 2004); and The Report of the Commission of Inquiry into Abuse of Children in Queensland Institutions (Brisbane: Queensland Government Printer, 2001).

2. Denise Cuthbert and Marian Quartly, "Forced Adoption in the Australian Story of National Regret and Apology," Australian Journal of Politics and History 58, no. 1 (2012): 82-96. 
3. Cuthbert and Quartly, "Forced Adoption."

4.ForMothersoftheWhiteStolenGeneration, seehttp://whitestolengeneration .com/.

5. Senate Community Affairs References Committee, Lost Innocents; Senate Community Affairs References Committee, Forgotten Australians.

6. For more information on the claims of mothers, see Cuthbert and Quartly, "Forced Adoption."

7. For the landmark Mabo judgment in the High Court of Australia, see http :// www. austhi.edu. au/au/cases/cth/hca/19 92/23 .html.

8. Royal Commission into Aboriginal Deaths in Custody, Final Report, 11 vols. (Canberra, 1991), available at http://www.austhi.edu.au/au/other/IndigLRes/rciadic/.

9. See the 2003 report of the Senate References Committee on the progress of reconciliation; it lists these issues and others, including Indigenous intellectual property rights, but makes no reference to forced child removal (Australian Senate, Legal and Constitution References Committee, Reconciliation: Off Track [Canberra, October 2003]).

10. Jacqui Katoni and Chips Mackinolty, eds., The Long Road Home: The Going Home Conference, 3-6 October 1994 (Darwin: Karu Aboriginal Child Care Agency, 1996); for Tickner's announcement, see Paul Kelly, The March of Patriots: The Struggle for Modern Australia (Parkville: University of Melbourne Press, 2009), 204.

11. Kevin Rudd, transcript of address at the apology to the Forgotten Australians and former child migrants, Great Hall, Parliament House, November 16, 2009, emphasis added, http://pandora.nla.gov.au/pan/110625/20091116-1801/www.pm.gov.au/node/632i.html.

12. Editorial, Age, February 13, 2008, http://www.theage.com.au/news /editorial/ the-hour-hascome-a-nation-says-sorry/2008/02/12/1202760300641 Jitml?page=2.

13. In borrowing the phrase "moral core of the nation," we distinguish our position from its author, the right-wing revisionist commentator Keith WindshutÜe: "Almost single-handedly, [historian Peter Read] took an issue [stolen children] from the very margins of significance and put it at the moral core of the nation" (http://www.stolengenerations.info/index.php?option=com_content \&view=article\&id=73 \&ltemid=3 1).

14. Bain Attwood, Telling the Truth about Aboriginal History (Crows Nest NSW: Allen \& Unwin, 2005). 
15. These exceptions include a vocal group of Stolen Generation deniers, including Keith Windshuttle, Michael Duffy, and Melbourne journalist Andrew Bolt. Windshuttle sums up the position of these revisionists: "As I have demonstrated throughout this book, no state or territory in Australia ever wanted to steal Aboriginal children from their parents in order to eliminate the race or put an end to Aboriginality No Aboriginal children were removed as part of an agenda driven by racism or genocide. There were no Stolen Generations" (The Fabrication of Aboriginal History, vol. 3, The Stolen Generations 1881-2008 [Macleay Press, December 2009]). Indicative of the persistence of this line of argument is the 2010 piece by Andrew Bolt, "The Death of the Stolen Generations Myth," Herald Sun, January 30, 2010, available at http://blogs.news.com .au/heraldsun/andrewbolt/index.php/heraldsun/comments/the_death_of _thestolen_generations_myth/. See also National Sorry Day Committee, "History of Sorry Day," http://wwwnsdc.org.au/index.php?option=com_content \&view=category\&layout=blog\&id=20\&Itemid=5i.

16. Attwood, Telling the Truth.

17. Daryl Sloane, Submission 57, http://www.aph.gov.au/Parhamentary

_Business/Committees/Senate_Committees?url=clac_ctte/recs_lost _innocents_forgotten_aust_rpts/submissions/subhst.htm.

18. Frank Golding, Submission 16, emphasis added, http://www.aph.gov.au /Parhamentary_Business/Committees/Senate_Committees?url=clac_ctte/recs _lost_innocents_forgotten_aust_rpts/submissions/subhst.htm.

19. Commonwealth of Australia, Official Committee Hansard, Senate Standing Committee on Community Affairs, Reference: Implementation of the Recommendations of the Lost Innocents and Forgotten Australians Reports, emphasis added, http://www.aph.gov.au/Parhamentary_Business/Committees/Senate _Committees?url=clac_ctte/recs_lost_innocents_forgotten_aust_rpts/hearings/index.htm.

20. James Murray, in Commonwealth of Australia, Official Committee Hansard, 19.

21. Leonie Sheedy, in Commonwealth of Australia, Official Committee Hansard, 47.

22. This line of argument (promulgated by Windshuttle, Bolt, and others listed above) was played out in the popular press and in the pages of the right-wing journal Quadrant from the mid-1990s to 2008 and beyond. See Quadrant at http://www.quadrant.org.au/.

23. Murray, in Commonwealth of Australia, Official Committee Hansard, 20. 
24.RichardYallop,"TheChildrenNobodyLoved,"Australian, September 1,2004, http://www.theaustralian.news.com.au/common/story_page/o,5744,io63ii5i \%5e28737,oo.html.

25. Australian Senate Standing Committee on Community Affairs, Lost Innocents and Forgotten Australians Revisited: Report on the Progress with the Implementation of the Recommendations of the Lost Innocents and Forgotten Australians Reports (tabled June 25, 2009), http://www.forgottenaustralians.com /pdf/FARevisitedreport.pdf.

26. Care Leavers Australia Network, "About clan: Our History and Objectives," http://www.clan.org.au/page.php?pagelD=i; Joanna Penglase, "Wardies and Homies: The Forgotten Australians" (n.d.), emphasis added, http://www .clan.org.au/page.php?pagelD=23.

27. Quoted in Penglase, "Wardies and Homies," 2.

28. Norman Johnston, Commonwealth of Australia, Official Committee Hansard, 1, emphasis added. This sentiment is echoed in the submission to the inquiry from the Child Migrant Trust (cmt) (Submission 23): "Indeed, many consider that this [the apology to the Stolen Generations] changed the moral and political landscape of Government attempts to address past wrongs" (quoted in the final report of the inquiry, Lost Innocents and Forgotten Australians Revisited, 19).

29. Murray, in Commonwealth of Australia, Official Committee Hansard, 20.

30. Penglase, "Wardies and Homies."

31. Additionally, over time the term "Stolen Generations" has come in popular discourse to represent any bad policy with respect to children and families, and the prospect of making further "Stolen Generations" has been mobilized by a range of groups for different purpose. See, for example, the open letter from the Family Council of Victoria to the Victoria parliament on the Assisted Reproductive Technology Bill (2009), "ART Bill: Creating Another Stolen Generation," http://www.fcv.org.au/art-bill-creating-another-stolen-generation.

32. James Luthy, 2008, Submission 36, http://www.aph.gov.au/Parhamentary _Business/Committees/Senate_Committees?url=clac_ctte/recs_lost_innocents _forgotten_aust_rpts/submissions/sublist.htm.

33. For a fuller discussion of this apology and its focus on the innocence of childhood, see Cuthbert and Quartly, "Forced Adoption."

34. Rudd, transcript.

35. Melissa Nobles, The Politics of Official Apologies (New York Cambridge University Press, 2008). 
36. The Senate, Community Affairs References Committee, Commonwealth Contribution to Past Forced Adoption Practices (Canberra: Parliament of Australia, 2012), 39,

http://www.aph.gov.au/Parhamentary_Business/Committees

/Senate_Committees?url=clac_ctte/comm_contrib_former_forced_adoption /report/index.htm.

37. As of May 2012, the Commonwealth Government had yet formally to respond to the report of the Senate committee and its recommendations.

38. Cuthbert and Quartly, "Forced Adoption."

39. Cuthbert and Quartly, "Forced Adoption."

40. Parliament of Tasmania, 1999; New South Wales Parliament, Legislative Council, Standing Committee on Social Issues, 2000.

41. Ann Fessier, The Girls Who Went Away: The Hidden History of Women Who Surrendered Children for Adoption in the Decades before "Roe v. Wade" (New York Penguin Press, 2006); Veronica StrongBoag, Ending Families, Finding Ourselves: English Canada Confronts Adoption from the 19th Century to the 1990s (Toronto:Oxford University Press, 2006); Jenny Keating, A Child for Keeps: The History of Adoption in England, 1918-1945 (London: Palgrave Macmillan, 2009).

42. Laura Briggs, Somebody's Children: The Politics of Transracial and Transnational Adoption (Durham: Duke University Press, 2012), 282.

43. This is close to Pauline Wakeham's formulation: "Reconciliation entails not a forgetting of the past but, rather, an active historicizing of the present" ("Reconciling 'Terror': Managing Indigenous Resistance in the Age of Apology," American Indian Quarterly 36, no. 1 [2012]: 26).

\section{About the authors}

*Denise Cuthbert is currently Dean of the School of Graduate Research RMIT in Melbourne, Australia; and a member of the research team undertaking the Australian Research Council-funded History of Adoption in Australia. Her recent work on adoption and related topics may be found in Australian Feminist Studies, Journal of Australian Studies, Australian Journal of Politics and History, the Journal of Historical Sociology and the International Journal of Social Welfare. She is the coeditor of a 2009 collection of essays, Other People's Children: Adoption in Australia (Australian Scholarly Publishing, 2009) and editor of a special issue of Social Policy and Society (2012: 11. 4) on intercountry adoption.

**Marian Quartly is a feminist historian whose work spans labour history, women's history and most recently the history of adoption in Australia. She leads the team which includes Denise Cuthbert and Shurlee Swain on the four-year Australian Research Council-funded History of 
Adoption in Australia. Marian is a co-author of the groundbreaking feminist history of Australia, Making a Nation, and has authored and co-authored many articles in Australian and international journals. Her recent work on adoption appears in Adoption and Culture, Journal of Australian Studies, Social Policy and Society, and Children Australia.

Copyright University of Nebraska Press Winter 2013 